\title{
Editorial:
}

\section{A New Journal and the Meanings of 'East Central' Europe}

Matthew Rampley (rampley@phil.muni.cz)

Department of Art History, Masaryk University, Brno, Czech Republic

\section{Keywords}

Austria-Hungary; cultural memory; modernity; Oskar Halecki; Friedrich Naumann; Larry Wolff

https://doi.org/10.5817/AEC2021-1-1 


\section{Editorial: A New Journal and the Meanings}

of 'East Central' Europe

We are proud to launch Art East Central as a journal that will act as a forum for scholarly articles and discussion on the art, architecture and design of East Central Europe since 1800. It will be the only such journal in English, and its aim is to disseminate knowledge and stimulate debate about the art and culture of a large geographical region that, for many, remains terra incognita.

What do we mean by East Central Europe? Geographical terms are often ideologically weighted, and none more so than 'east' and 'central' Europe. As Larry Wolff argued over 20 years ago, the notion of 'eastern Europe' is a product of the Enlightenment and was enmeshed in the wider geopolitical division of Europe (itself a problematic term). ${ }^{1}$ Equally, the idea of Central Europe was long associated with Prussian military and diplomatic ambitions, having been coined by the liberal politician Friedrich Naumann to designate the territory that should be subject to German cultural and political hegemony. ${ }^{2}$ No term is neutral, but we have chosen 'East Central Europe,' first used by the Polish historian Oskar Halecki in 1943. It is not without its own problems, but Halecki employed it to buttress a claim about setting up a more inclusive understanding of European identity, and it is now a widely accepted designation. ${ }^{3}$

For Halecki East Central Europe denoted the countries between Germany and the then Soviet Union, consisting of Hungary, Poland, Czechoslovakia and Yugoslavia. Behind this lay a particular vision, for it consisted of those lands whose historical experience had been shaped either by the Polish-Lithuanian Commonwealth or by Austria-Hungary. Our understanding is more inclusive, for it encompasses, too, the states of the Balkan Peninsula as well as those in the Baltic littoral. Hence, in this, the very first issue, we discuss a book of essays on art history writing in Greece, for example.

Histories and cultures were intertwined and entangled; the visual arts of south-eastern Europe were profoundly shaped over the past 200 years by their intimate connections with Austria-Hungary and the Ottoman Empire, as were those of Ukraine. Indeed, in recent years the historic ties of western Ukraine to the former Habsburg Empire, when it formed the crownland of Bukovina and the eastern half of Habsburg Galicia, have led to the creation of a local heritage industry based on the role of Czernowitz (now: Chernivtsi) and Lemberg (now: L'viv) as Habsburg lieux de mémoire. Halecki's definition focused on the political future of those countries that were the subject of Nazi German and Soviet aggression and military occupation. As such, it excluded Austria, but Art East Central takes it as axiomatic that since Austria was at the heart of the Habsburg Empire, it, too, comes into our sphere of interest, not least since it encompassed the capital of Austria-Hungary, Vienna.

1) Larry Wolff, Inventing Eastern Europe: The Map of Civilization on the Mind of the Enlightenment, Stanford: Stanford University Press, 1996.

2) Friedrich Naumann, Mitteleuropa, Berlin: Georg Reimer, 1915.

3) Oskar Halecki, 'East Central Europe in Postwar Organization,' Annals of the American Academy of Political and Social Science, 232:1, 1943, 9-18. 
Political and state boundaries are artificial constructs, and we are therefore open to contributions on topics that fall outside the geographical boundaries of East Central Europe, if they impinge upon or help shape the critical understanding of our area of focus. The idea of East Central Europe goes beyond mere geographical definitions to comprise a broad cultural zone, its coherence based on shared memories. Uppermost among these is the experience of modernity in perhaps its most violent and disruptive forms; on the political level alone one can describe the historical experience of East Central Europe as one founded in interruptions. In no area of Europe - perhaps, even, of the world - have borders been drawn and redrawn more frequently. This process has never been one of mere administrative adjustment, but also one of physical displacement of populations, large-scale destruction and rebuilding of landscapes - urban and rural - and reorganisation of social structures and cultural relations. One can point, too, to the complex linguistic and demographic composition of nearly every territory in East Central Europe over the past two centuries and to its implications for the impact of processes of modernization. If, in France or Britain, modernity was intimately bound up with the experience of empire, in East Central Europe it meant both the creation of multi-lingual and multi-ethnic cultures on a hitherto unparalleled scale and resistant nationalisms based on ideologies of monolingualism and ethnic purity. The reshaping of the social sphere in the nineteenth and twentieth centuries meant that older, pre-modern, forms of cohabitation accommodating cultural and linguistic diversity came under severe pressure; the new forms of sociality that emerged with modernity became a focus of unprecedented competition and rivalry for status and hegemony. Art, architecture and, later, design, became intimately drawn into this process and served as a medium for the articulation of ever shifting identities, as well as the exploration and questioning of aesthetic norms.

Art East Central is founded on the premise that while, over the past twenty years, East Central Europe has managed to gain a place on the map of art history, its presence is still tentative. The emergence of global art history has ensured the long overdue 'provincializing' of Europe, as Deepesh Chakrabarty has termed it, and renewed attention to the art, architecture and design in East Central Europe can be viewed as part of that same process. ${ }^{4}$ The art history of East Central Europe has its own role to play in wider global questions. ${ }^{5}$

Debates continue over how to conceptualise the relation between art centres in East Central Europe - Kaunas, Warsaw, Budapest, Belgrade, for example, - and those, such as Paris, Berlin, New York and Moscow, that have dominated the historiography of art hitherto. The tentative presence of east central European art is also often due to the pragmatic fact that knowledge of most of the languages of East Central Europe are little known outside of their respective linguistic communities. The same could not be said of, for example, Spanish, English or French, for example, which, due to the legacy of empire, have a global reach, or of Italian and German which, for reasons to do with their traditional prestige within the discipline, continue to be internationally used languages. Hence, research on art and architecture in, for example, Poland, Hungary, Estonia or Romania is little read outside of these respective states, and even less is undertaken by scholars based elsewhere. Art East Central is consequently motivated by

4) Deepesh Chakrabarty, Provincializing Europe: Postcolonial Thought and Historical Difference, Princeton: Princeton University Press, 2000.

5) On this issue see Beata Hock and Anu Allas, eds, Globalizing East European Art Histories: Past and Present, London, Taylor and Francis, 2018. 
the sense that much work remains to be done, if this zone of Europe is to claim appropriate critical international attention of art historians. It is of course no small irony that we choose English as the language of publication. Yet it has fast become the lingua franca of art history and nowhere more so than in Central Europe. Our use of it may perhaps also be justified by the fact that despite its role as a tool of global intellectual and cultural hegemony, it has, in East Central Europe at least, never had any associations with the political domination and imperial rule that characterised much of the history of the region over the past two centuries.

A brief final note should be added about our chronological range. Chronological divisions are often arbitrary and, to some degree, reflect the preoccupations and values of whoever sets them. Interested in publishing papers on art, architecture and design up to the present day, we take as our starting point 1795, the year of the final partition of Poland. A catastrophe for the Polish state and a marker of the power of the ambitions of Russia, Prussia and Austria, it nevertheless coincided with the growing influence of the French revolution, that traditional marker of political modernity in Europe. Our primary focus is therefore on publishing papers that explore the distinctive experience of modernity in East Central Europe, as it was expressed and reflected on in architecture and the visual arts. However, as with the question of geography, we are open to contributions on topics that fall outside of this strict boundary, but which we feel have salience and significance for our broader concerns. 